\title{
IAMJ
}

INTERNATIONAL

AYURVEDIC

MEDICAL JOURNAL

\section{A CASE STUDY ON AYURVEDIC MANAGEMENT OF AMAVATA (RHEUMATOID ARTHRITIS)}

\author{
Mulay Monica ${ }^{1 *}$, Gopale Neha ${ }^{2 *}$ \\ ${ }^{1}$ Assistant Professor, Panchakarma Department, Tilak Ayurved Mahavidyalaya, Pune 11., Maha- \\ rashtra, India \\ ${ }^{2}$ PG Scholar, Panchakarma Department, Tilak Ayurved Mahavidyalaya, Pune 11., Maharashtra, \\ India
}

Corresponding Author: monica.mulay@gmail.com

\section{https://doi.org/10.46607/iamj4509082021}

(Published Online: August 2021)

Open Access

(C) International Ayurvedic Medical Journal, India 2021

Article Received: 04/07//2021 - Peer Reviewed: 11/07/2021 - Accepted for Publication: 15/07/2021

\section{Check for updates}

\begin{abstract}
Amavata is a very painful condition in day-to-day life. It is a chronic disorder related to especially sandhisthanas (joints). It can be compared with Rheumatoid Arthritis (R.A.). In modern medicine, R.A. is treated with steroids and various NSAIDS which has multiple side - effects. In Ayurveda, Amavata is caused due to impairment of Agni (indigestion) and vitiation of Vata dosha which form 'Aama - The untransformed, non-assimilated component in the digestive process.' Amavata is a madhyama rogamarga disease and causes severe pain, stiffness and is difficult to treat. Hence, there are chances of recurrence. For this, in Ayurveda, both Shamana and Shodhana treatments are explained very well. In this case study, the patient was dependent on steroids and her physiological functioning body was hampered. By Ayurvedic intervention (Shodhana and Shamana Chikitsa) we have effectively manage the disease by gradually tapering the steroids and ultimately stopped. The sequential treatment plan is effectively used in this case.
\end{abstract}

Keywords: Amavata, Aama, Shamana, Shodhana. 


\section{INTRODUCTION}

The words 'Aama' and 'Vata' unite to form the word 'Amavata'. This suggests the predominance of these 2 factors in the pathogenesis of Amavata. It can be compared with Rheumatoid Arthritis. The worldwide prevalence of R.A. is estimated between $0.3 \%$ to $1 \%$ and common in women of developed countries ${ }^{(1)}$. In India, the prevalence is estimated to be $0.75 \%{ }^{(2)}$. In Ayurveda, Aama - the untransformed, nonassimilated component in the digestive process is lodged in Kapha sthanas especially 'sandhi' (joints). According to Acharya Madhavakara, vitiated vata and Aama simultaneously moves into sandhis leading to stabdhata (stiffness) and severe pain in the extremities ${ }^{(3)}$. Amavata presents in different forms like $s a$ manya, pravruddha, jeerna (chronic), Nava (newly diagnosed), sometimes Vata dominant, sometimes Aama dominant. In Amavata, symptoms of Aama are seen all over the body. Aggravated and vitiated Vata dislodges Aama to the kaphasthanas (places) mainly Amashaya, Sandhi (joints), Uraha (chest region), kantha, shirah (head) and produces symptoms such as Angamarda (body ache), Aruchi (tastelessness), trushna (thirst), Aalasya (laziness), Gaurava (heaviness), Jwara (fever), Apaka (indigestion), shotha (inflammation), shunata (swelling of body parts) ${ }^{(4)}$. Amavata can be presented as acute or chronic or drug dependent. It is difficult to treat drug-dependent diseases. Sometimes we must taper the dose or stop the drug with appropriate protocol and then start Ayurvedic treatment. Acharya Yogaratnakara explained the principal treatment of Amavata as langhana (fasting), swedana (steam) in the form of both dry and wet, deepana (ignition of digestive fire), virechana (purgation), Snehapana (internal medication in the form of oil/ghee/bone marrow), Basti (medicated drug administered through the anal region) ${ }^{(4)}$

\section{Case Report}

A 54-year-old female patient came to our OPD complaining of pain and swelling at both metacarpophalangeal joints, pain and stiffness of both wrist joints mainly right side, knee joint pain, pain and swelling of both ankles joint for 14 years. These symptoms increased for 5-6 years. Also, she had complaints of body ache, heaviness, laziness and anorexia for the last 10 days.

History of Present Illness: The patient was without any symptoms before 14 years then she had complaints of pain and swelling of both metacarpophalangeal joints followed by pain and swelling of both knee joint, wrist joint and ankle joint. The patient had taken allopathy medicines which includes steroids results in some pain relief. After few years, the same complaints repeated, and the intensity of pain was increased. The patient was dependent on steroids. For complete relief, the patient came to our hospital for Ayurvedic treatment.

History: The patient had no history of high blood pressure, Diabetes mellitus, Asthama and epilepsy.

Surgical History: Hysterectomy in 2005.

Medical History: Patient had taken -

- Tablet Folitrax $10 \mathrm{mg}$ (once a week)

- Tablet Homin (once daily)

- Tablet Pantin 40mg (once daily)

- Tablet HCQ 300mg (once at night)

- Tablet Zinvita (once at night)

- Tablet Nuxib (as per need)

- Tablet Fevimax $-\mathrm{Z}$ (once at night)

The patient was dependent on steroids for 5 years. When we started our Ayurvedic treatment, we tapered the dose of steroids in such a way that the time interval between the two doses of the tablet (steroid) was increased gradually and ultimately stopped. Since then, the patient was without steroids.

Family History: The patient's mother had paralysis for 4 years and grandmother had Sandhigatavata.

\section{Clinical findings:}

1. General Examination - Pulse - 86/minute (Vata dominance, heavy), Blood pressure 110/80mmofHg, Respiratory rate- 20/minute, Temperature $-97.2^{\circ} \mathrm{F}$, Height $-148 \mathrm{~cm}$, Weight - $60.830 \mathrm{~kg}$, Oxygen saturation - 99\%

2. Ashtavidha Pariksha: Nadi - 86/minute (vata dominance, heavy), Mala - once a day, proper consistency, yellow, Mutra - 5-6 times per day, once a night, Jivha - white. Coated, Shabda - 
Proper, Sparsh - not too hot or cold, Druka pale, Aakruti - medium stature
4. Srotasa Examination

5. Samprapti (Pathogenesis)

3. Prakruti - Vata dominance pitta

Table 1: Examination of Srotasa (Channels)

\begin{tabular}{|l|l|l|l|}
\hline Strotasa & Darshan (inspection) & Sparshan (Palpation) & Prashna (Questions) \\
\hline Annavaha & & $\begin{array}{l}\text { Udara } \\
\text {-Alpa Gaurava }\end{array}$ & Anannabhilasha (Anorexia) \\
\hline Rasavaha & Panduta (pallor), Raukshya (dryness) & & $\begin{array}{l}\text { Chintadhikya (excessive thought), } \\
\text { Shabda asahishnuta (discomfort while hear- } \\
\text { ing a sound), Angasada (body ache) }\end{array}$ \\
\hline Mansavaha & $\begin{array}{l}\text { Daurbalya (weakness) } \\
\text { Sandhivedana (joint pain) }\end{array}$ \\
\hline Asthivaha & $\begin{array}{l}\text { Swelling of both metacarpophalangeal } \\
\text { joint, wrist joint, ankle joint, knee } \\
\text { joint. }\end{array}$ & $\begin{array}{l}\text { Ushna (hot), } \\
\text { Sparshasahatva (pain } \\
\text { on palpation) }\end{array}$ & $\begin{array}{l}\text { Pain at both metacarpophalangeal joint, wrist } \\
\text { joint, knee joint, ankle joint }\end{array}$ \\
\hline Manovaha & & & Stress, Fear. \\
\hline
\end{tabular}

\section{Factors -}

- Dosha - Vata - Vyana, Samana, Pitta - Pachaka, Sadhaka, Kapha-Shleshaka, kledaka

- Dushya-Rasa, Rakta, Mamsa, Asthi

- Affected Strotasa - Annavaha, Rasavaha, Rakatvaha, Mamsavaha, Medovaha, Asthivaha

- Rogamarga-Madhyam

- Udbhavasthana-Amashaya

- Vyaktasthana-Sandhi (joints)

- Roga swabhava-Chirakari (Chronic)

Investigation: RA Factor - positive, C-Reactive Protein - Positive (7.68 mg / L), ESR - $62 \mathrm{~mm} / \mathrm{hr}$., All other routine blood investigations were within the normal limit.

Diagnosis: Based on the presentation of symptoms, pathogenesis and investigations, the diagnosis was considered as Amavata. (Jeerna Avastha- chronic).

\section{Assessment:}

1. Grading of Sandhishoola (Pain)

No pain - 0

Mild pain - 1

Moderate, but no difficulty in moving - 2

Much difficulty in moving the body parts - 3

2. Grading of Sandhishotha (swelling)

No swelling - 0

Slight swelling - 1

Moderate swelling - 2
Severe swelling - 3

3. Grading of Sparshasahatwa (tenderness)

No tenderness - 0

The subjective experience of tenderness -1

Wincing of the face on pressure - 2

Wincing of face and withdrawal of the affected part on pressure- 3

4. Gradation of walking time (for 25 feet in several seconds)

15-20 seconds - 0

21-30 seconds -1

31-40 seconds - 2

More than 40 seconds - 3

\section{Material and Method (Treatment Plan) -}

- After being treated with other pathies and having no significant result, the patient came to our hospital for Ayurvedic treatment. The disease was chirakari (chronic) and dosha is deep-seated (leena dosha) and in Saama avastha ${ }^{(5)}$.

- For that, we first performed Pachana karma with Abhyantar chikitsa (internal medicine) then panchakarma treatments like Sarvang Abhyanga (whole-body massage), Bashapa Sweda (steam), Patrapottali sweda according to doshadhikya, dushya, rugna bala etc.

- After Pachana karma, along with internal medicine, Sarvang abhyanga, Bashpa sweda we went 
for Sthanik pinda sweda, Anuvasana Basti with Doshotkleshana taila ${ }^{(6)}$ and later on Prasarani Taila $^{(7)}$ with intermittent Niruha Basti of Bruhat Erandmooladi $^{(8)}$
- Meanwhile, we tapered the steroid and then stopped.

- On discharge, the patient had advised the internal medicine to maintain the health.

Table 2: Abhyantar Chikitsa (Internal Medicine) for Pachana

\begin{tabular}{|l|l|}
\hline Day & Medicines used for treatment \\
\hline $\mathrm{D}_{1}-\mathrm{D}_{40}$ & Suvarnalakshmivilas Rasa ${ }^{(9)} 125 \mathrm{mg}$, Morning - evening each with honey \\
\hline & Amapachaka vati $500 \mathrm{mg}$, thrice a day with warm water \\
\hline & Poonarnava churna ${ }^{(10)} 250 \mathrm{mg}$, thrice a day with warm water \\
\hline & Deodara Churna ${ }^{(10)} 250 \mathrm{mg}$, thrice a day with warm water \\
\hline & Sukumar kashaya 2 tablespoons thrice a day along with warm water. \\
\hline
\end{tabular}

Table 3: Panchakarma treatment for Pachana and After Pachana

\begin{tabular}{|c|c|c|}
\hline Day & Panchakarma Treatment & Drug used \\
\hline \multirow[t]{2}{*}{$\begin{array}{l}\mathrm{D}_{30^{-}} \quad \mathrm{D}_{41} \text { (After } \\
\text { pachana) }\end{array}$} & $\begin{array}{l}\text { Sarvanga Abhyanga (whole } \\
\text { body massage) }\end{array}$ & Prasarani Taila $(\text { oil })^{(7)}$ \\
\hline & Bashpa sweda (steam) & Dashamoola kwatha (decoction) \\
\hline $\mathrm{D}_{30}-\mathrm{D}_{35}$ & Patrapottali sweda & $\begin{array}{l}\text { Erandapatra }+ \text { Nirgundi patra }+ \text { Prakshepa }(\text { Deodara churna }+ \text { Rasna } \\
\text { churna }+ \text { Mishreya }+ \text { Prasarani Taila })\end{array}$ \\
\hline $\mathrm{D}_{35}-\mathrm{D}_{41}$ & Sthanika Pinda sweda & Dashamoola-Ashwagandha siddha ksheerodana \\
\hline \multirow[t]{2}{*}{ From $\mathrm{D}_{30}$} & Anuvasana (oil) Basti & $\begin{array}{l}\text { Doshotkleshana Taila } 60 \mathrm{ml} 7 \text { Basti given), Prasarani Taila } 60 \mathrm{ml} \text { (7 } \\
\text { Basti given) }\end{array}$ \\
\hline & Niruha (decoction) Basti & Bruhata Erandmooladi $400 \mathrm{ml}$ (2 Basti given) \\
\hline
\end{tabular}

Table 4: Abhyantara treatment as Rasayana (Rejuvenation)

Day Medicine used

$\mathrm{D}_{41}$ (On discharge this medicine will continue for Capsule Dhanwantar 101

the next 30 days.)
2 Cap. Early in the morning

Ashwagandha churna ${ }^{(10)} 500 \mathrm{mg}$ thrice a day

Deodar churna ${ }^{(10)} 250 \mathrm{mg}$ thrice a day

Tablet Tapyadiloha ${ }^{(9)} 250 \mathrm{mg}$ trice a day

Suvarnalakshmivilas Ras $^{(9)} 125 \mathrm{mg}$ Morning - evening each with honey.

Sukumar kashaya 2 tablespoons thrice a day along with warm water.

\section{Observation and Result}

1. Assessment of Sandhishoola

\begin{tabular}{|l|l|l|l|l|}
\hline Name of Joint & Left & Right & \multicolumn{1}{|l|}{$\mid$} \\
\hline Metacarpophalangeal joint & BT & AT & BT & AT \\
\hline Wrist joint & 2 & 1 & 2 & 1 \\
\hline Knee joint & 3 & 1 & 2 & 0 \\
\hline Ankle joint & 2 & 0 & 2 & 0 \\
\hline Shoulder joint & 2 & 0 & 2 & 0 \\
\hline
\end{tabular}


2. Assessment of Sandhishotha

\begin{tabular}{|l|l|l|l|l|}
\hline Name of Joint & Left & \multicolumn{3}{l|}{ Right } \\
\hline Metacarpophalangeal joint & BT & AT & BT & AT \\
\hline Wrist joint & 2 & 1 & 2 & 1 \\
\hline Knee joint & 2 & 1 & 1 & 0 \\
\hline Ankle joint & 1 & 0 & 1 & 0 \\
\hline
\end{tabular}

3. Assessment of Sparshasahatva

\begin{tabular}{|l|l|l|l|l|}
\hline Name of Joint & Left & Right & \\
\hline & BT & AT & BT & AT \\
\hline Metacarpophalangeal joint & 1 & 0 & 1 & 0 \\
\hline Wrist joint & 2 & 1 & 2 & 0 \\
\hline Knee joint & 1 & 0 & 1 & 0 \\
\hline Ankle joint & 2 & 0 & 2 & 0 \\
\hline
\end{tabular}

4. Assessment of walking time

\begin{tabular}{|l|l|l|}
\hline Criteria & BT & AT \\
\hline $\begin{array}{l}\text { Walking Time } \\
\text { (For 25 feet in several seconds) }\end{array}$ & 2 & 1 \\
\hline
\end{tabular}

Follow up: The patient came for follow up after one month. The above-mentioned complaints were reduced and had $70 \%$ relief. The patient had advised taking the same internal medicine which was given on discharge along with some healthy diet including black rasene, almond etc. for the next 21 days.

\section{DISCUSSION}

The patient is suffering from joint pain for the last 14 years. She had taken allopathy medicines for that but had no significant result. Then patient came to our hospital for Ayurvedic management. During the examination, we found that the patient was in Saamaa avastha and had leena (deep-seated) dosha. Also, the patient was sukumara and having less dhatu bala. So first we performed Pachana karma (digestion of elevated dosha and aama). For that, we used Amapachaka vati which acts on pachakagni and helps to digest the Aama. Poonarnava churna and Deodar churna used both were acts as Shothaghna (antiinflammatory), Vata-kaphahara (elimination of Vata and Kapha dosha), deepana (ignition of digestive fire). These medicines were used along with Sukumara kashaya which was for Deepana karma (ignition of Agni-digestive fire), Bruhana karma (nourishment) and Shothagna (Anti-inflammatory) and Vataghna. Also, we used Suvarnalakshmivilas rasa which acts on leena dosha (deep-seated) and in jeerna samprapti (prolong pathogenesis), Vata -Kapha dominance and acts as an immunomodulator, cardioprotective, anti-inflammatory and did dhatuposhana (nourishment) and Rasayana karma(rejuvenation). Along with internal medicines we used panchakarma treatment. For pachana (digestion of Aama) we used patrapottali sweda (Erandapatra + Nirgundi patra + Deodara churna + Rasna churna + Mishreya + Prasarani Taila) along with Sarvanga abhyanga (Prasarani taila) and Bashpa sweda. Prasarani taila acts on sira, snayu sthambha (muscles stiffness) and release that stambha and decrease the vitiated Vata dosha, hence it was used for both Abhyanga and patrapottali sweda. Bashpa sweda (steam) with Dashmoola decoction is done to counteract stambha(stiffness) and Gaurava (heaviness) results in pacification of vata and reduction in joint stiffness. Patrapottali sweda results in dhatugata Aama pachana. After pachana, we hold patrapottali sweda and starts sthanik pinda sweda (Dashmoola churna + 
Ashwagandha churna + Ksheerapaka + Odana) which pacifies Vata in joints and strengthens Snayu (muscles) and kandara (tendon) and gives nourishment along with sarvanga snehana and Bashpa sweda. For leena dosha (deep-seated), we used Doshotkleshana basti which stimulate and liquifies the dosha and does shakha koshata gati -the transformation of vitiated dosha from extremities towards abdomen. After shakha koshata gati, we used Bruhata erandamooladi niruha for the elimination of vitiated doshas from koshta (abdomen). After Doshotkleshana Basti, we started Prasarani taila matra basti for rest of pachana and Bruhana karma. From this treatment, the patient got $70 \%$ relief. To maintain the status of the patient we used the same internal medicine including Capsule Dhanwantar 101 as snehana for a longer period and Tapyadi loha for Bruhana (nourishment) and Rasayana karma (rejuvenation)

\section{CONCLUSION}

As Amavata is difficult to treat, a sequential treatment plan is effectively used in this patient. In this case, the patient was sukumara with madhyam bala and the disease was in jeerna avastha (chronic). So, we used treatments that did Pachana, Vatashamana, Bruhana and Rasayana karma for a longer time. The patient has got $70 \%$ relief from this treatment.

\section{REFERENCES}

1. WHO.int [ internet]. Geneva: World Health Organization; c 2016 [updated 2016; cited 2016 May 11].

2. Malaviya A.N., Kapoor S.K., Singh R.R., Kumar A., Pande I. Prevalence of rheumatoid arthritis in the adult Indian population. Rheumatol Int. 1993; 13(4): 131134. [PubMed].

3. Acharya Narendranath Shastree, Madhava Madhukosha Teeka, Amavata Nidana Adhyaya 25, Motilal Banarasidasa Prakashana Delhi, Edition 1979.

4. Vd. Shastri Lakshmipati,Yogaratnakara, Amavata chikitsa Adhyaya, Chaukhamba prakashana Varanasi, Edition 2013.

5. Bramhananda Tripathi, Ashtanga Hridaya, Sutra sthana, Doshopakramaniya adhyaya 13/28-31, Chaukhamba Sanskrita Pratishthana Delhi, 2015
6. Kaviraj Ambikadutta Shastri, Sushruta Samhita, Chikitsa sthana, Niruhakrama chikitsa Adhyaya 38/93, Chaukhamba Sanskrit Sansthan, Varanasi, 2016.

7. Dr Bramhanand Tripathi, Sharangadhar Samhita, Madhyam Khanda, Snehakalpana Adhyaya, 9/119123. Chaukhamba Surabharati Prakashana Varanasi, Edition 2013

8. Bramhananda Tripathi, Ashtanga Hridaya, Sutra sthana, Bastikalpam adhyaya 4/7-10, Chaukhamba Sanskrita Pratishthana Delhi, 2015

9. Vaidyapanchanana Gangadhara Shastri Gopalarao Gune, Ayurvediya Aushadhi gunadharma shastra, Sau. L.P. Vaidya prakashana, Pune.

10. Dr Deshpande, Dr Javlagekar, Dr Ranade, Dravyagunavigyan, Proficient Publishing House, Edition 2013.

\section{Source of Support: Nil Conflict of Interest: None Declared}

How to cite this URL: Mulay Monica \& Gopale Neha: A Case Study On Ayurvedic Management Of Amavata (Rheumatoid Arthritis). International Ayurvedic Medical Journal \{online\} 2021 \{cited August 2021\} Available from: http://www.iamj.in/posts/images/upload/1888_1893.pdf 